\title{
AN ESSAY ON CONSUMPTION HYPOTHESES: EVIDENCE FROM PAKISTAN
}

\author{
Khalid Khan*, Marguerite Wotto ${ }^{\dagger} \&$ Saima Liaqat ${ }^{\ddagger}$
}

\begin{abstract}
In this study, the ARDL method is used to assess short-term and longterm relationships between private consumption, labor income, interest rate, wealth, and unemployment rate. The real private consumption model for Pakistan has been estimated by applying yearly data from 1990 to 2016. According to long-term estimates, income and wealth determine the actual national consumption. Nevertheless, the short run national private consumption is determined by current incomes, wealth, real interest rates, and the unemployment rate. Findings of this study reveal significant impact of all the observed determinants of consumption function i.e. real disposable income, wealth, real interest rate, and unemployment rate on aggregate consumption. Whereas it is noteworthy that the coefficient for wealth was minor but significant, depicting slight impact of wealth on consumption decision. These results support validity of AIH for Pakistan.
\end{abstract}

Keywords: Real private consumption, Absolute income hypothesis (AIH), Autoregressive distributed lag model (ARDL)

\section{Introduction}

In macroeconomics, the relationship between consumption and disposable income is one of the oldest and most important phenomena. This relationship is named as consumption function. The consumption function is one of the central ideas of Keynes's general theory. Keynes explained the

\footnotetext{
Department of Economics, Lasbela University of Agriculture, Water and Marine Sciences (LUAWMS), Uthal, Balochistan

$\dagger$ Faculty of Educational Sciences, University of Quebec at Montreal (UQAM), Canada (marguerite_wotto@yahoo.fr)

\$ Department of Economics, University of Queensland, Brisbane, Australia and The Lahore College for Women University, Jhang Campus (saima.liaqat@jhang.lcwu.edu.pk)
} 
relationship between consumption and disposable income as a common sense, that's why, he described this phenomena as psychological law of consumption in his book General Theory.

Keynes explained the psychological law of consumption in his book in the following words:

"The fundamental psychological law, upon which we are entitled to depend with great confidence both a priori from our knowledge of human nature and from the detailed facts of experience, is that men are disposed, as a rule and on the average, to increase their consumption as their income increases, but not by as much as the increase in their income. Keynes (1936)"

In the fundamental psychological law of consumption, Keynes just relied on general sense about human natures but did not provide any rational-choice theory or empirical support to his theory. However, he also ignored utility maximization. The basic idea of Keynes's consumption function is that the main determinant of household's current consumption is current disposable income.

Later, Simon Kuznets pointed out a paradox about Keynes's consumption function, which is known as Kuznets paradox. Kuznets tested the Keynes's consumption function empirically with US data and proved that in the long run APC of consumption function remained constant. However, in short run Kuznets's results are consistent with Keynes's consumption function. Earlier response which comes to answer the Kuznets's paradox was Relative Income Hypothesis (RIH) by Duesenberry (1949), Permanent Income Hypothesis (PIH) by Milton Friedman in 1957 and Life Cycle Hypothesis (LCH) by Franco Modigliani, Albert Ando, and Richard Brumberg (1950). These theories were introduced by different economists after each other, for better understating and explanation of household's consumption behavior; due to the importance of consumption in aggregate economic activities and to spur economic growth.

However, the AIH and PIH have different views about MPC, the AIH hypothesis believes in high value of MPC while PIH supposes a smaller value of MPC as compared to AIH. However, the value of MPC is very critical for multiplier effect. Because, through multiplier we accelerate and control aggregate economic activities in a country, higher the value of MPC makes sure high value of multiplier effect \& vice versa. Therefore, for policy makers it is very important to know the correct value of MPC in a country and to understand the consumption behavior of households that what types of consumption hypothesis is prevailing in a country. Similarly, economic growth and employment also depends on the value of multiplier and MPC. Aggregate real private consumption is encompassed over half of aggregate economic expenditure and half of GDP, which makes it very important and indeed very interesting area for research. Moreover, most of 
the researchers and policy makers are interested in aggregate real private consumption due to its role in achievement of a high and stable long run economic growth. The aggregate consumption links with economic growth in the following possible ways.

Firstly, during recession when economy needs big push and to speed up the aggregate economic activities, at that time aggregate real private consumption works very well.

Secondly, aggregate real private consumption is the counterpart of aggregate saving and aggregate saving feeds the financial institution of the countries to meet investors' demand, high saving will lead to high investment and output. Thus, the better understating of aggregate real private consumption will help in better understating of aggregate saving.

Thirdly, it is generally believed that the determinants of consumption vary from country to country. Therefore, in this study we want to test that; is there are any difference between the determinants of aggregate real private consumption in a developing country like Pakistan and general theory for the rest of the world.

Fourth, the key features of economic growth of any country are consumption, investment and saving. Therefore, to understand the pattern of economic growth of country, it is indispensable to understand the consumption pattern of that country because saving and investment are the counterparts of consumption and are very strongly linked to consumption. Thus, for better understanding of Pakistan's economy it is important to know the factors effecting aggregate consumption.

\section{Objective of the Study}

The aggregate real private consumption is one of the major components of GDP in Pakistan counting around $80 \%$ of GDP while in less developed countries it is usually recorded about 75 to 90 percent. It is one of the important factors for decision makers to accelerate aggregate economic activities by accelerating the aggregate real private consumption during recession; likewise, it also works during boom to control the aggregate economic activities. Therefore, the objective of this study is, to understand the nature of households' consumption pattern in Pakistan as aggregate consumption is one of the key determinants of business cycle and economic growth in the country. Moreover, it indicates that for the understanding of business cycle and economic growth of the country, first we need to understand the nature of aggregate real private consumption which is also key concern for policy makers.

\section{Literature Review of the Study}

The survey of literature on aggregate private real consumption provides mixed results about the validity of $\mathrm{AIH}$ and PIH for different countries based 
on the determinants of aggregate consumption. However, the following main points can be underlined. First, the most prominent consumption hypotheses are AIH, RIH, PIH and LCH by (Khan et al 2016). Among these consumption hypotheses, $\mathrm{AIH}$ and $\mathrm{PIH}$ are widely tested for different types of countries (developing, less developed and developed countries). Nevertheless, the RIH and LCH are not very popular for empirical testing and have not been tested so widely. Secondly, in the year 1978 two seminal studies came out and introduced different methodologies for estimating consumption function, which has been applied by various researchers and economists since 1978. These seminal studies were: Hall (1978) rational expectation hypothesis and DHSY (1978) and Davidson et al (1978) formulation of Error Correction Model (ECM) for estimation of aggregate real private consumption. Henceforth, this study applies Davidson et al (1978) procedures to estimate the consumption function for Pakistan. Thirdly, in empirical literature of testing the consumption hypothesis, AIH and PIH are very popular while RIH did not get too much attention due to data availability problem. However, PIH and LIH have the same optimization model based on expected income and both hypotheses draw the same conclusion. Likewise, this study is also looking-forward to test AIH and PIH for Pakistan through determinants of aggregate consumption.

Khan et al (2014) examined the trends of aggregate real private consumption for G7 countries (Canada, France, Germany, Japan, Italy, UK and USA) for the period of 1990-2014. Furthermore, he also investigated the determinants of aggregate private consumption in case of G7 countries. The study highlights that the main determinants of aggregate real private consumption are households' income, saving, GDP, wealth, and employment condition. Khan (2012) tested Hall's PIH for Pakistan using time series date from 1992 to 2010 and consisted AIH for Pakistan while results of the Campbell and Mankiw consumption model indicate that 68 percent of the households' consumption decisions were based on rule of thumb while the remaining households were forward looking.

The rest of the study is organized as follows: section two devoted to methodology. Section three and four are based on empirical results and conclusion of the study, respectively.

\section{Methodology}

\section{Consumption Function Modeling}

Following Modigliani and Brumbergh (1954), Ando and Modigliani (1963), Hassan Shivani and Barry Wilbratte (2009), Khan et al ( 2017), Manzoor et al (2018), and Saima et al (2020): the study considers the subsequent consumption function: $\mathrm{C}=f(\mathrm{Y}, \mathrm{W}, I, U r)$. Where $(\mathrm{Y})$ is assigned for income, $(\mathrm{C})$ is aggregate national consumption, (W) is wealth, (i) real interest rate and (ur) unemployment rate. Henceforth, the data of the variables are obtained from the CD of the WDI from 1990 to 2018. The 
national income is adjusted with GDP deflator while aggregate consumption and real interest rate are deflated with 2005 based year Consumer Price Index (CPI). Moreover, the study will be using proxies for wealth and interest rate. The proxy which is used for wealth is quasi money while discount rate is considered proxy for interest rate.

Beforehand the selection of any econometrics method, first we are interested to put the data for unit root test to check if the data is stationary at level or not. To test the stationarity of the data Augmented Dickey-Fuller (ADF) test is applied. The results of ADF test are reported in Table 01. The results of the ADF test revealed that all the variables are stationary at first different despite the real interest rate which is stationary at level.

Table 1: Unite Root Results of the Variables

\begin{tabular}{|c|c|c|c|}
\hline Variables & Lag 1 & Lag 2 & Lag 3 \\
\hline $\mathbf{C}$ & -1.5299 & -1.0259 & -0.3178 \\
\hline$\Delta_{C}$ & $-4.9486 * * *$ & $-5.4242 * * *$ & $-3.9197 * *$ \\
\hline $\mathbf{Y}$ & -0.7321 & 0.5904 & -0.475 \\
\hline$\Delta_{Y}$ & $-3.3733^{*}$ & $-3.2082 *$ & -2.5439 \\
\hline $\mathbf{W}$ & -2.9211 & -2.5664 & -1.8193 \\
\hline$\Delta_{W}$ & $-5.1362 * * *$ & $-5.7355 * * *$ & $-3.5422 * *$ \\
\hline $\mathbf{r}$ & $-3.2622 *$ & -3.0299 & -2.1229 \\
\hline$\Delta_{r}$ & $-5.4022 * * *$ & $-5.9741 * * *$ & $-5.4706^{* * *}$ \\
\hline ur & -2.2187 & -1.8807 & -2.3728 \\
\hline$\Delta_{\text {ur }}$ & $-4.9130 * * *$ & $-3.3491 *$ & $-3.3881 *$ \\
\hline
\end{tabular}

Note: ***, **, * indicate 1\%, 5\% and $10 \%$ level of significance respectively.

As variables of the model are mix of both integrated of order one and two. Therefore, in this situation the conventional co-integration techniques are not apt to estimate the connotation among the variables. Moreover, these conventional co-integration techniques will also not offer the robust parameters of the variables. Therefore, the study has applied the ARDL techniques which are most appropriate in the given situation. It provides reliable parameters of both short run and long run, besides, several advantages of the ARDL technique over other co-integration techniques. The ARDL technique gives more robust results in case of small sample and resolves the problem of endogeneity. Moreover, it is applicable without pretesting of a unit root for the variables and the capacity to hold more exogenous variables than any other co-integration methods. Hence, conclusively the ARDL model of the consumption function is as underneath: 
$\Delta \ln C_{t}=\alpha_{0}+\sum_{i=0}^{n} \alpha_{i} \Delta \ln Y_{t-i}+\sum_{i=0}^{n} \delta_{i} \Delta \ln W_{t-i}+\sum_{i=0}^{n} \eta_{i} \Delta \ln C_{t-i}+\sum_{i=0}^{n} \psi_{i} r_{t-i}+$

$\sum_{i=0}^{n} \rho_{i} u r_{t-i}+\gamma_{1} \ln Y_{t-1}+\gamma_{2} \ln W_{t-1}+\gamma_{3} \ln C_{t-1}+\gamma_{4} r_{t-1}+\gamma_{5} u r_{t-1}+u_{t}$

Where: $\rho_{i}$ holds short run while $\gamma_{i}$ comprehend the long run information. Thus, to detect the co-integration among the variables of equation (1) the subsequent hypotheses are tested.

$H_{0}=\gamma_{1}=\gamma_{2}=\gamma_{3}=\gamma_{4}=\gamma_{5}=0$ and

$H_{1}=\gamma_{1} \neq \gamma_{2} \neq \gamma_{3} \neq \gamma_{4} \neq \gamma_{5} \neq 0$.

The first hypothesis provides evidence that there is no co-integration while the later shows co-integration among the variables.

\section{Results and Discussion}

Nevertheless, for testing of the hypothesis of equation 10 the study applied the bounds test of co-integration. The critical values of the bound test are reported in table 02 .

\section{Table 2: Critical Values of the Bound Test for Co-Integration Test}

\begin{tabular}{ccc}
\hline Critical Value & Lower Bond & Upper Bond \\
\hline $1 \%$ & 2.425 & 3.574 \\
$5 \%$ & 2.850 & 4.049 \\
$10 \%$ & 3.817 & 5.122 \\
\hline
\end{tabular}

The calculated F-statistics for co-integration is 8.00, which is superior over all to bound test critical values. Hence based on this the null hypothesis is rejected and it is concluded that there is long run association among the variables. Error correction model (ECM) is estimated after validation and determination of long and short term associations between the variables of the model estimated order to derive the speed of correction to convergence from divergence.

$$
\begin{aligned}
\Delta \ln C_{t}=\phi & +\varphi(E C M)_{t-1}+\sum_{i=0}^{n} \alpha_{i} \Delta \ln Y_{t-i}+\sum_{i=0}^{n} \delta_{i} \Delta \ln W_{t-i}+\sum_{i=0}^{n} \eta_{i} \Delta \ln C_{t-i}+\sum_{i=0}^{n} \psi_{i} r_{t-i} \\
& +\sum_{i=0}^{n} \rho_{i} u r_{t-i}+\varepsilon_{t}(6)
\end{aligned}
$$


Table 3: Results of the ARDL model

\begin{tabular}{cccc}
\hline Variables & Coefficient & T-Values & P-Values \\
\hline $\boldsymbol{C}_{\boldsymbol{t}-\mathbf{1}}$ & 0.41710 & $3.8387 \mathrm{~s}$ & $\mathbf{0 . 0 0 1}$ \\
$\boldsymbol{Y}$ & 0.71352 & 3.8437 & $\mathbf{0 . 0 0 1}$ \\
$\boldsymbol{Y}_{\boldsymbol{t}-\mathbf{1}}$ & -0.39180 & -1.7598 & $\mathbf{0 . 0 8 8}$ \\
$\boldsymbol{W}$ & -0.49059 & -2.9564 & $\mathbf{0 . 0 0 6}$ \\
$\boldsymbol{W}_{\boldsymbol{t}-\mathbf{1}}$ & 0.75355 & 4.7632 & $\mathbf{0 . 0 0 0}$ \\
$\boldsymbol{r}$ & $1.83 \mathrm{E}+08$ & 3.5820 & $\mathbf{0 . 0 0 1}$ \\
$\boldsymbol{u} \boldsymbol{}$ & $-2.92 \mathrm{E}+08$ & -1.0125 & $\mathbf{0 . 3 1 9}$ \\
$\boldsymbol{u} \boldsymbol{r}_{\boldsymbol{t}-\mathbf{1}}$ & $7.42 \mathrm{E}+08$ & 2.3348 & $\mathbf{0 . 0 2 6}$ \\
& & & \\
$\boldsymbol{R}^{2}$ & 0.99686 & Adj: $\boldsymbol{R}^{2}$ & $\mathbf{0 . 9 9 6 1 8}$ \\
$\mathbf{A I C}$ & -897 & SBC & $\mathbf{- 9 0 4}$ \\
$\mathbf{D W}$ & $\mathbf{2 . 1 9 4 5}$ & F-Sat $(\mathbf{7 , 3 2})$ & $\mathbf{1 4 5 2}(\mathbf{0 . 0 0 0})$ \\
\hline
\end{tabular}

Note: *, **,*** indicate significance level on 1\%, 5\% and $10 \%$.

Table 04 reports the parameters of the long run association among the variables of the model. It demonstrates that the coefficients of unemployment and interest rates are not statistically significant. Nevertheless, the coefficients of the wealth and labor income are carrying an appropriate sing and they are statistically significant. Hence, it shows that wealth and labor income have positive effects on aggregate consumption of Pakistan.

Table 4: Long Run Results of ARDL

\begin{tabular}{cccc}
\hline Variables & Coefficient & T-Values & P-Values \\
\hline$Y$ & 0.80304 & 2.9552 & $\mathbf{0 . 0 0 6}$ \\
$W$ & 0.12171 & 1.9565 & $\mathbf{0 . 0 5 9}$ \\
$r$ & -0.001571 & -.49890 & $\mathbf{0 . 6 2 1}$ \\
$u r$ & $\mathbf{0 . 0 0 1 1 8 8}$ & $\mathbf{0 . 6 8 6 9}$ & $\mathbf{0 . 4 9 7}$
\end{tabular}

Table 05 outlines the error correction model (ECM) results. The ARDL based error correction model shows that all the variables are statistically significant except unemployment. The ECM coefficient is statistically significant; it has negative sign i.e. -0.58 , which implies a high speed of convergence to equilibrium. This means that deviation for long-term equilibrium will be corrected by 58.00 percent each year. 
Table 5: ECM Results

\begin{tabular}{cccc}
\hline Variables & Coefficient & T-Values & P-Values \\
\hline$\Delta Y$ & 0.71352 & 3.8437 & $\mathbf{0 . 0 0 0}$ \\
$\Delta W$ & -0.49059 & -2.9564 & $\mathbf{0 . 0 0 6}$ \\
$\Delta \boldsymbol{r}$ & $1.83 \mathrm{E}+08$ & 3.5820 & $\mathbf{0 . 0 0 1}$ \\
$\Delta u \boldsymbol{E}$ & $-2.92 \mathrm{E}+08$ & -1.0125 & $\mathbf{0 . 3 1 9}$ \\
$\boldsymbol{E} \boldsymbol{C M}(-\mathbf{1})$ & -0.58290 & -5.3646 & $\mathbf{0 . 0 0 0}$ \\
$\boldsymbol{R}^{2}$ & 0.75258 & Adj: $\boldsymbol{R}^{2}$ & $\mathbf{0 . 6 9 8 4 5}$ \\
AIC & -897 & SBC & $\mathbf{- 9 0 4}$ \\
DW & $\mathbf{2 . 1 9 4 5}$ & F-Sat $(\mathbf{4 , 3 5})$ & $\mathbf{2 4}(\mathbf{0 . 0 0 0})$ \\
\hline
\end{tabular}

\section{Conclusion}

The assessment of the consumption function in Pakistan, based on the ARDL approach, shows that current income and assets have a significant impact on the country's actual private consumption in the long run. The coefficient values for current income and long-term assets/wealth are 0.80 and 0.12 , respectively which indicates that $80 \%$ of consumers' consumption decisions are based on current incomes, whereas just $12 \%$ private consumption is influenced by present and future wealth. Therefore, we can conclude that the assumption of absolute income in aggregate consumption is applicable in Pakistan. Consequently, the decision of consumers depends heavily on current income while weakly on wealth, current interest rates and employment opportunities. Further, the findings provide evidence for consumer behavior to be determined by all the relevant variables described above in the short run.

\section{References}

Bimal, S., (2004) "Modeling Real Private Consumption Expenditure - An Empirical Study on Fiji," Economics Department Reserve Bank of Fiji Suva Fiji, Working Paper 2004/05 December 2004

Campbell, J.Y. and Mankiw, N.G., (1989) "Permanent Income, Current Income and Consumption," Journal of Business and Economic Statistics, 8, pp.265-279.

Dejuan. J.P., (2006) "Testing the Permanent Income Hypothesis New Evidence from West-German States (Lander)," Journal of Empirical Economics, 31, pp.613-629.

Dejuan. J.P. and Seater J.J., (1997) “A Cross Country Test of the Permanent Income Hypothesis," International Review of Applied Economics, 11: 451-468. 
Drakos, K., (2002) "Myopia, Liquidity Consumption Constraints, and Aggregate Consumption the Case of Greece," Journal of Economics Development, 27(1), pp. 97-105.

Duesenberry, J.S., (1948) "Income Saving and the Theory of Consumption Behavior," Cambridge: Harvard University Press, 1948.

Engle, R.F. and Granger, C.W.J. (1987), "Cointegration and Error Correction: Representation, Estimation and Testing”, Econometrica; 55: 251-276.

Flavin, M.A., (1981) "The Adjustment of Consumption to Changing Expectation about Future Income," Journal of Political Economy, 89, pp.974-1009.

Friedman, M., (1947) “A Theory of the Consumption Function”, Princeton: Princeton University press 1956.

Habibullah M.S., Smith, P., and Azaman, S., (2006) "Testing Liquidity Constraint in 10 Asian Developing Countries an Error Correction Model Approach," Applied Economics, 38: pp.2535-2543.

Hall, R.E., (1981) "Intertemporal Substitution in Consumption," Journal of Political Economy, 96, pp.339-987.

Hall, R.E., (1978) "Stochastic Implication of the Life Cycle Hypothesis Theory and Evidence," Journal of Political Economy, 86, pp.971-98.

Hsich W.J. and Hsing, Y., (1994), "Tests of Nonlinear Consumption Function: the Case of Korea, Taiwan, Thailand and India," International Economics Journal, 8:pp.71-81.

Johansen, S., Juselius, K. (1990), "Maximum likelihood estimation and inference on co-integration with applications to the demand for money", Oxford Bulletin of Economics and Statistics 51, 169-21.

Johansen, S. (1988), "Statistical analysis of co-integration vectors", Journal of Economic Dynamics and Control; 12: 231-254.

Johansen, S. (1996), "Estimation and Hypothesis Testing of Cointegration Vectors in Gaussian Vector Autoregressive Models", Econometrica; 59(6): 1551- 1580.

Keynes, J.M., (1936) The Genera Theory of Employment Interest and Money, London Macmillan, 1936.

Khan, K., \& Nishat, M. (2011). Permanent Income Hypothesis, Myopia and Liquidity Constraints: A Case Study of Journal of Social Sciences (PJSS), 31(2), 299-307.

Khan, K., Anwar, S., Ahmed, M., \& Kamal, M.A. (2015). Estimation of Consumption Functions: The Case of Bangladesh, India, Nepal and Sri Lanka. Business Review, 17(1), 113-124.

Khan, K., \& Che, M.H.M. (2012). The Testing of Hall's Permanent Income Hypothesis: A Case Study of Asian Economic and Financial Review, 2(4), 518.

Khan, K. (2015). Real Private Consumption Modeling of VFAST Transactions on Education and Social Sciences, 5(1). 
Khoon, L.G. and Richard, D., (2002). "Modeling New Zealand Consumption Expenditure over the 1990s," New Zealand Treasury, Working Paper 02/19.

Kuznets, S., (1946). National product since 1869 (assisted by L. Epsteion and E. Zanks), New York, National Bureau of economics research, (1946).

Lavi, Y., (2003) "Do Changes in Current Income Help to Explain Changes in Consumption in Israel," Journal of Israel Economics Review, 2, pp.113-135.

Liu, (2007), "Hong Kong's Consumption Function Revised," Hong Kong Monetary Authority Working Paper. No 16/2007.

Lucase, Robert E. Jr. (1976). "Econometric Policy Evaluation: A Critique," in Carnegie-Rochester Conferences on Public policy 1, 19-46.

Manitsaris, A., (2006). "Estimating the European Union Consumption Function Under the Permanent Income Hypothesis," International Research Journal of Finance and Economics, 2.(2006).

Modigliani, F. and Brumbergh, R., (1954) "Utility Analysis and The Consumption," Economics Journal, 88, pp.661-692.

Pesaran, H.M., and Pesaran, B. (1997). Microfit 4.0: Interactive Econometric Analysis. Oxford University Press: England.

Pesaran, H.M., Shin, Y. and Smith, R.J. (2001). Bounds Testing Approaches to the Analysis of Level Relationships. Journal of Applied Econometrics, 16, 289-326.

Pesaran, H.M., and Shin, Y. (1999). Autoregressive Distributed Lag Modelling Approach to Cointegration Analysis, Chapter 11, in Storm, S., (ed.), Econometrics and Economic Theory in the 20th. Century: The Ragnar Frisch Centennial Symposium. Cambridge University Press: Cambridge.

Roa, B.B., (2007). "Testing the Permanent Income Hypothesis in the Developing and Developed Countries a Comparison between Fiji and Australia," School of Economies University of the South Pacific, Working paper No2007/09.

Roa, B.B., (2005). "Testing Hall's Permanent Income Hypothesis for a Developing Country The case of Fiji," Journal of Applied Economics Letter, 12, pp.245-248.

Shea, J., (1991). "Myopia, Liquidity Constraints, and Aggregate: A Simple Test," Journal of Money, Credit, and Banking, 27(3), pp. 798-805.

Shirvani, H. and Wilbratte, B., (2008). "The Permanent Income Hypothesis in Five Major Industrial Countries: a Multivariate Trend-Cycle Decomposition Test," Journal of Economics Finance, 33: pp.43-59.

Zeldes, S.P., (1989). "Consumption and Liquidity Constraints an Empirical Investigation,” Journal of Political Economy, 97, pp.305-345. 